\title{
Production of Biodiesel from Locally Available Spent Vegetable Oils
}

\author{
M. M. Al Naggar, F. H. Ashour, R. S. Ettouney and M. A. El Rifai \\ Chemical Engineering Department, Faculty of Engineering, Cairo University, Egypt \\ m_anagar@hotmail.com, fhashour@eng.cu.edu.eg
}

\begin{abstract}
The depletion of fossil fuels prompted considerable research targeting the development of alternative fuel sources. Biodiesel production has acquired increasing importance owing to its renewable nature and milder environmental impacts. To this end, alternative sources of feedstock have been sought and studies aiming at the optimization of the production procedure have been carried out. Millions of liters of waste frying oil are produced from local restaurants and houses every year, most are discarded into sewage systems damaging networks and complicating the treatment process. This study is intended to consider aspects related to the feasibility of the production of biodiesel from waste frying oils in order to alleviate the waste frying oil pollution problems as well as to reduce the cost of biodiesel production. Locally available spent vegetable oils have been collected from different sources and accordingly have somewhat different chemical compositions. The conducted experiments involved the production of biodiesel from the different feed stocks using the base catalyzed trans-esterification process. The quality of the produced biodiesel is compared to petro-diesel in terms of established standard specifications.
\end{abstract}

\section{INTRODUCTION}

Increase of energy usage in the industrialized world entails rapid depletion of nonrenewable fossil fuels and is associated with pollution problems [1]. Renewable resources of energy include solar energy, wind energy, geothermal energy, tidal energy, ocean thermal energy, hydropower, and alternative combustible fuels [2]. Production of alternative fuels should be technically feasible, economically competitive, environmentally acceptable, and readily available [1]. Diesel engines are the main engines used in industrial, transport and agricultural applications due to their high efficiency and reliability [3]. Diesel engines operate via compression ignition where the fuel is injected in the engine's cylinder with compressed air at high pressure and temperature. The fuel self-ignites and burns rapidly when it enters the cylinder forcing the piston back down and converting the chemical energy in the fuel into mechanical energy. The fuel used in the first diesel engine, developed by Dr. Diesel in 1895, was vegetable oil. This, however, poses socio-economic arguments arising from the conflict between food shortage and the demand for energy. Due to the availability and low cost of petroleum diesel fuel, vegetable oil-based fuels are not used widely except in times of high oil prices and shortages as in World War II and the oil crisis of the 1970's. At present, vegetable oils are not directly used as alternative fuels due to their high viscosity, incomplete combustion, injection and ring coking and may ultimately cause engine failure $[4,5]$. Vegetable oils, as a source of biodiesel production, include sunflower, safflower, soybean, cottonseed, rapeseed, and peanut oils. Vegetable oil based fuels are the attractive alternative for diesel fuel due to their renewable nature, better ignition quality, comparable energy content, high density, higher flash point, nontoxic emissions, cleaner burning, nearly zero sulfur content, high cetane number and high calorific value close to diesel fuel $[6,7]$.

There are many reasons that encourage search for alternative compression ignition engine fuels. Conventional diesel engine fuels are associated with smoke and nitric oxide (NOx) emissions. More stringent governmental regulations targeting cleaner combustion have been imposed to reduce diesel engine emissions. This can be done by engine development with fuel reformulation and use of alternative fuels [3]. The alternative sources considered include oils of plant origin [1]. Bio-fuel, namely biodiesel and ethanol, is predicted to replace petroleum diesel fuel [8]. The ethanol is used for gasoline engines and biodiesel for compression ignition engines [9]. Many countries such as Brazil, the United States, Germany, Australia, Italy and Austria are currently using bio-fuel; however, its economic feasibility should be improved before it could be widely used. In most countries, the governments support biodiesel usage by reducing its 
cost through tax rebates [10]. According to the American Society for Testing and Materials (ASTM), biodiesel is defined as mono-alkyl esters of long chain fatty acids derived from vegetable oils and animal fats. "Bio" represents its biological and renewable source, and "diesel" implies its use as a fuel on diesel engines [11]. Biodiesel is derived from renewable biomass sources thus it represents a closed carbon dioxide cycle (approximately 78\%) [12].

The chemical structure of methyl esters depends on the length and degree of un-saturation of the fatty acid alkyl chains. The degree of un-saturation of methyl esters affects the carbon to hydrogen ratio which is slightly different from conventional diesel fuel. The oxygen content is the important difference between conventional diesel fuel and biodiesel because biodiesel contains $10-12$ wt\% oxygen [13, 14 , 15]. The burning efficiency of biodiesel is improved due to its high oxygen content; thus, it corresponds to lower particulate matter (PM), carbon monoxide (CO), and hydrocarbon ( $\mathrm{HC})$ emissions, however, and it produces higher NOx emissions [16].

The purpose of this work is to conduct a laboratory scale study for production of biodiesel using locally gathered waste vegetable oils from different origins. The processing requirements for the different feed stocks are to be compared. The final product specifications are to be also compared with those of petro diesel.

\section{EXPERIMENTAL CONDITIONS}

Trans-esterification reactions have to be carried out under vigorous mixing conditions owing to the immiscibility of the oil and methanol phases. Since trans-esterification is a relatively slow process, intense mixing is required both because of the relatively high oil viscosity and in order to ensure sufficient interfacial area between the two reactants present in different phases. The optimum operating temperature for this reaction is $65^{\circ} \mathrm{C}$, which is slightly above the boiling point of methanol $\left(64.7^{\circ} \mathrm{C}\right)[17]$. When the reaction temperature exceeds the boiling point of methanol, the methanol will vaporize and form a large number of bubbles which may inhibit the reaction. The experimental conditions for the different feed stocks have been fixed at an agitation rate of $400 \mathrm{rpm}$ and at a temperature of $65^{\circ} \mathrm{C}$.

\section{MATERIALS AND METHODS:}

Waste oil was collected from three different sources: (1) waste frying palm oil (WPO) from a local fast food restaurant, (2) mixed waste home frying oil used only once or twice (WHO), (3) waste mixed oils, sunflower, palm oil and soya oil (WTO) collected after 48 working hours from a controlled food court. The chemicals used in the experiments were: methanol procured from El-Nasr Pharmaceutical Chemicals Co. (ADWIC) with a molecular weight of 32.04 and an assay of $99.8 \%, \mathrm{KOH}$ purified pellets from ThannFransu, analar grade isopropyl alcohol, and phenolphthalein.

A small-scale laboratory setup was used for pretreatment and trans-esterification experiments. The waste oil is first heated to $60^{\circ} \mathrm{C}$ in a water bath to ensure complete melting. It is then filtered using a standard Buchner funnel connected to a vacuum pump in order to ensure complete solids removal. The filtrate is then heated in a water bath up to $110^{\circ} \mathrm{C}$ to ensure vaporization of any residual water since the presence of water negatively affects the reaction by promoting saponification and increasing the viscosity. Trans-esterification experiments were conducted in triplicate using $100 \mathrm{~g}$ of used frying oil. Methanol and $\mathrm{KOH}$ catalyst were poured into a clean reaction flask provided with a magnetic stirrer and a reflux condenser. The oil, methanol, and $\mathrm{KOH}$ mixture was stirred for $120 \mathrm{~min}$ at $60-70^{\circ} \mathrm{C}$ and $400 \mathrm{rpm}$. The trans-esterification reaction was carried out for different ratios of oil to methanol $(10,15,20,30$, and $40 \mathrm{~g}$ ). The amount of catalyst had a pronounced influence on the conversion to esters. Various amounts $(0.75 \mathrm{~g}, 1 \mathrm{~g}$, and $1.5 \mathrm{~g})$ of $\mathrm{KOH}$ catalyst were used in the experiments: After the trans-esterification reaction, the biodiesel was separated from glycerol using a separating funnel where the reaction mixture was allowed to cool. Clear separation was observed after 12-24 hours of settling. The ester was then washed three times with warm distilled water. The product was then dried by heating at $110^{\circ} \mathrm{C}$ for 30 min to remove the moisture content and the methyl ester is filtered to remove any residual soap.

The effects of catalyst content, methanol to oil molar ratio, and reaction time were determined. It is recognized that the production of waste cooking oil will be a function of the frying temperature and length of use as well as the material used for frying.

The free fatty acid (FFA) analysis for the raw oil 
should be lower than $0.5 \%$. The oil has been treated and the FFA content was determined by standard titration while the fatty acid composition was determined using chromatographic analysis (GC).

\section{RESULTS AND DISCUSSION:}

\section{- Yield and Conversion}

The effect of base-catalyzed trans-esterification process variables on biodiesel yield from the different waste frying oils was investigated by changing the $(\mathrm{KOH})$ catalyst to oil ratios $(\% \mathrm{w} / \mathrm{w})$ and the methanol to oil ratios $(\% \mathrm{w} / \mathrm{w})$.

Table 1.Yield and Conversion of Trans-esterification Reaction of all Waste Frying Oils

\begin{tabular}{|c|c|c|c|c|c|c|c|c|}
\hline \multirow{2}{*}{ Run\# } & \multirow{2}{*}{$\begin{array}{c}\text { KOH } \\
(\mathbf{g})\end{array}$} & \multirow{2}{*}{$\begin{array}{c}\text { Meth. } \\
\mathbf{( g )}\end{array}$} & \multicolumn{3}{|c|}{ Yield \% } & \multicolumn{3}{|c|}{ Conversion \% } \\
\hline & & WPO & WTO & WHO & WPO & WTO & WHO \\
\hline 1 & 0.75 & 10 & & & 63.69 & & & 32.41 \\
\hline 2 & 0.75 & 15 & 81.41 & 67.25 & 78.22 & 76.92 & 55.56 & 61.38 \\
\hline 3 & 0.75 & 20 & 76.21 & 86.35 & 87.71 & 61.54 & 55.56 & 61.03 \\
\hline 4 & 0.75 & 30 & 87.05 & 75.73 & 85.14 & 76.92 & 77.78 & 62.07 \\
\hline 5 & 0.75 & 40 & 90.26 & 88.06 & 87.25 & 76.92 & 66.67 & 31.72 \\
\hline 6 & 1 & 10 & 34.53 & & 71.18 & 69.23 & & 60.34 \\
\hline 7 & 1 & 15 & 77.53 & 54.2 & 91.06 & 61.54 & 55.56 & 42.07 \\
\hline 8 & 1 & 20 & 87.18 & 80.04 & 91.41 & 69.23 & 55.56 & 80.69 \\
\hline 9 & 1 & 30 & 84.66 & 83.27 & 88.01 & 84.62 & 77.78 & 42.76 \\
\hline 10 & 1 & 40 & 88.26 & 84.08 & 68.96 & 84.62 & 55.56 & 42.17 \\
\hline 11 & 1.5 & 10 & 45.9 & & & 69.23 & & \\
\hline 12 & 1.5 & 15 & 70.66 & 73 & 83.89 & 38.46 & 55.56 & 50.35 \\
\hline 13 & 1.5 & 20 & 78.19 & 79.4 & 72.37 & 61.54 & 66.67 & 42.41 \\
\hline 14 & 1.5 & 30 & 88.59 & 77.12 & 67.85 & 76.92 & 77.78 & 60.21 \\
\hline 15 & 1.5 & 40 & 81.64 & 89.6 & 54.48 & 53.85 & 83.33 & 42.05 \\
\hline
\end{tabular}

Table 1 presents the calculated yield and conversion obtained from the experimental data for the different waste frying oils under different reaction conditions.

Previous results reported in the literature [17] on the effect of catalyst and methanol to oil ratio on biodiesel production suggest that biodiesel with the best properties was obtained using $1 \% \mathrm{KOH}$ by weight as the catalyst. Methanolysis with this catalyst produced the best yields and viscosities of the resulting esters. A. B. Chhetri et al. [12] used $0.4 \%, 0.6 \%, 0.8 \%, 1.0 \%$ and $1.2 \%$ sodium hydroxide as a catalyst and observed that no reaction took place with the $0.4 \%$ $\mathrm{NaOH}$. With catalyst concentrations of $0.6 \%, 0.8 \%$ and $1.0 \%$, ester yields were approximately $50 \%, 94 \%$ and $40 \%$, respectively. It was also observed that the ester yield decreased with the increase in $\mathrm{NaOH}$ concentration. With $1.2 \%$ catalyst concentration, soap formation was pronounced. Increased soap formation caused the ester to dissolve into the glycerol layer.

The findings obtained in the present work may be compared with the above literature data by considering the experimental results presented in Figures (1-3) below. Figure (1) presents the yields obtained for WPO, WHO, and WTO respectively for different amounts of $\mathrm{CH}_{3} \mathrm{OH}$ and $\mathrm{KOH}$.

It is seen that the highest yield for WPO ranged between $87.05 \%$ to $90.26 \%$ (runs $4,5,8,10$, and 14 ). In these runs, the dominant catalyst amount ranged between $(0.75-1 \mathrm{~g})$ except for run 14 which used $1.5 \mathrm{~g} \mathrm{KOH}$. Two runs (runs 6,11 ) gave a very low yield $(34.53 \%, 45.9 \%)$ and no yield was obtained for run (1). All of these runs were carried out using $10 \mathrm{~g}$ $\mathrm{CH}_{3} \mathrm{OH}$, and as such the amount of methanol is not sufficiently in excess to increase the rate of the forward reaction towards ester production.

The maximum yield for (WHO) was found in runs (7, $8,9)$ where the amount of catalyst was $(1 \mathrm{~g})$ and the amount of methanol was $(20,15,30 \mathrm{~g})$, respectively. No yield was obtained from run number (11) while the lowest yield was obtained in runs $(1,10,14$, and 15), where the high amount of $\mathrm{KOH}(1.5 \mathrm{~g})$ reduced the yield due to saponification (runs 14,15 ) and the low amount of methanol caused incomplete reaction (run 1). Also the increase of methanol reduced the yield because it diluted the reaction mixture (runs 10, 14 and 15). Thus the optimum trans-esterification reaction conditions for (WHO) were $1 \mathrm{~g} \mathrm{KOH}$ and $20 \mathrm{~g}$ methanol.

The maximum yield for (WTO) was in runs $(3,5,9,10$, and 15) with $\mathrm{KOH}$ ranging between $0.75 \mathrm{~g}$ and $1 \mathrm{~g}$ except for run 15 which used $1.5 \mathrm{~g} \mathrm{KOH}$. The lowest yield was in runs $(2,7)$ and no reaction took place in runs $(1,6$, and 11). All of these runs were carried out with methanol ranging between $(10-15 \mathrm{~g})$, and this means that the amount of $\mathrm{CH}_{3} \mathrm{OH}$ should not be lower than $(20 \mathrm{~g})$ to push the reaction in the forward direction. Thus, in the case of using (WTO) the optimum amount of $\mathrm{CH}_{3} \mathrm{OH}$ required to achieve a high yield is $(20 \mathrm{~g})$.

Comparison of the yields of the three types of oil showed that the highest yield was obtained for (WHO) in runs $(8,7)$ reaching $91.41 \%$ and $91.06 \%$, respectively. This is attributable to that (WHO) had the lowest FFA content and thus it gave higher yields 
under the same conditions. The second highest yield was obtained in run (5) for (WPO). Yields for both (WPO) and (WTO), at low amounts of $\mathrm{CH}_{3} \mathrm{OH}(10-$ $15 \mathrm{~g}$ ), were very low and sometimes no reaction occurred.

The highest conversion of $84.62 \%$ was obtained for (WPO). The second highest conversion of $83.33 \%$ was for (WTO) while the highest conversion using (WHO) was $80.69 \%$.

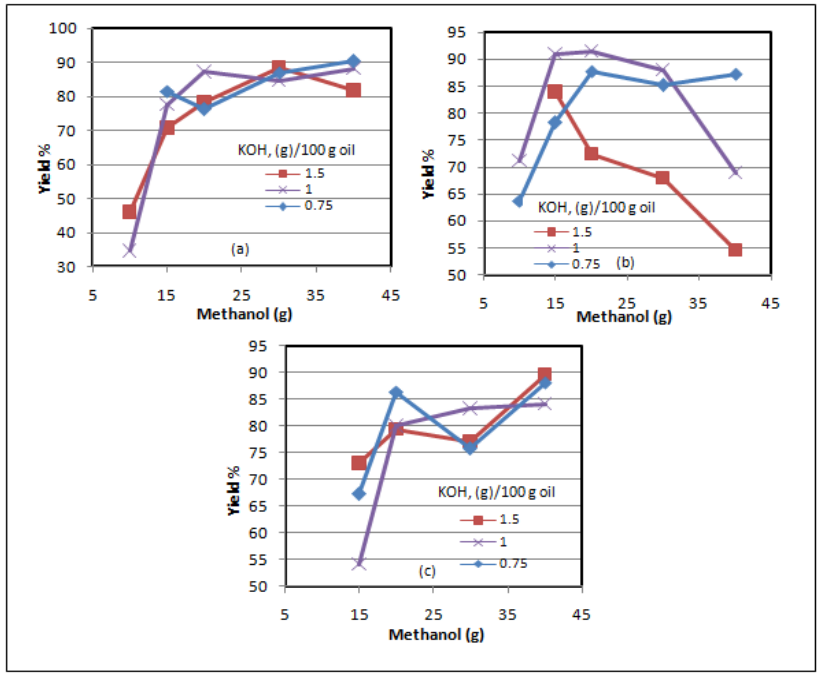

Fig .1. Effect of catalyst content on yield (a) WPO, (b) WHO and (c) WTO

\section{- Density and Viscosity}

Table 2 presents the density and viscosity of the produced Fatty Acid Methyl Ester (FAME) from WPO, WHO, and WTO respectively for different amounts of $\mathrm{KOH}$ and $\mathrm{CH}_{3} \mathrm{OH}$. The FAME density should lie between 0.86 and $0.9 \mathrm{~kg} / \mathrm{m}^{3}$ [11]. All the (WPO) densities were within the above specified range except for run (10) which gave a lower density $(0.849$ $\mathrm{kg} / \mathrm{m}^{3}$ ). All the measured (WTO) and (WHO) densities were equal to or higher than the upper limit of the specification. Figure (2) displays the measured kinematic viscosities (KV) for the FAME produced from WPO, WHO, and WTO, respectively. The range for biodiesel kinematic viscosity is $\left(1.9-6 \mathrm{~mm}^{2} / \mathrm{s}\right)$ according to ASTMD 6751 standard and (3.5 - 5 $\mathrm{mm}^{2} / \mathrm{s}$ ) accords to EN14214 standard. The measured (KV) at $40^{\circ} \mathrm{C}$ for (WPO) was $52.9 \mathrm{~mm}^{2} / \mathrm{s}$, for (WHO) was $33.5 \mathrm{~mm}^{2} / \mathrm{s}$, and for (WTO) was $52.1 \mathrm{~mm}^{2} / \mathrm{s}$. Most of the produced FAME was within the ASTM range except for run (1) for (WHO) and runs (2, 3, 7, and 12) for (WTO). In these runs, low amounts of methanol were used and as such (WTO) require more methanol to improve FAME characteristics. For (WPO) the out of specification runs were $(2,6,7,11$, and 12). All of these runs were carried out using low amounts of methanol and, accordingly, their viscosities were higher than the standards. Palmitic acid was the major saturated fatty acid found in this waste oil which is the major factor that determines the viscosity of biodiesel. Finally, the recorded decrease in density and viscosity after trans-esterification indicates that good trans-esterification has been achieved under appropriate experimental conditions.

Table 2.Density and Viscosity of FAME from all Waste Frying Oils

\begin{tabular}{|c|c|c|c|c|c|c|c|c|}
\hline \multirow{2}{*}{ Run\# } & \multirow{2}{*}{$\underset{(\mathrm{g})}{\mathrm{KOH}}$} & \multirow{2}{*}{$\begin{array}{l}\text { Meth. } \\
\text { (g) }\end{array}$} & \multicolumn{3}{|c|}{ Density $\mathbf{k g} / \mathbf{m}^{3}$} & \multicolumn{3}{|c|}{ Viscosity $\mathrm{mm}^{2} / \mathrm{s}$} \\
\hline & & & WPO & wTo & WHO & WPO & wTo & WHO \\
\hline 1 & 0.75 & 10 & & & 0.91 & & & 6.6 \\
\hline 2 & 0.75 & 15 & 0.889 & 0.92 & 0.91 & 6.14 & 9.2 & 5.6 \\
\hline 3 & 0.75 & 20 & 0.8924 & 0.91 & 0.91 & 5.63 & 6.7 & 4.8 \\
\hline 4 & 0.75 & 30 & 0.8856 & 0.90 & 0.90 & 4.88 & 5.2 & 4.6 \\
\hline 5 & 0.75 & 40 & 0.8844 & 0.90 & 0.90 & 5.05 & 4.9 & 4.5 \\
\hline 6 & 1 & 10 & 0.899 & & 0.90 & 8.31 & & 5.1 \\
\hline 7 & 1 & 15 & 0.891 & 0.91 & 0.91 & 6.11 & 8.7 & 4.9 \\
\hline 8 & 1 & 20 & 0.8818 & 0.90 & 0.90 & 5.08 & 4.9 & 4.4 \\
\hline 9 & 1 & 30 & 0.885 & 0.90 & 0.90 & 4.53 & 4.9 & 4.2 \\
\hline 10 & 1 & 40 & 0.849 & 0.90 & 0.91 & 4.88 & 5.1 & 4.7 \\
\hline 11 & 1.5 & 10 & 0.896 & & & 7.37 & & \\
\hline 12 & 1.5 & 15 & 0.894 & 0.90 & 0.91 & 6.4 & 6.6 & 4.7 \\
\hline 13 & 1.5 & 20 & 0.8832 & 0.90 & 0.91 & 4.84 & 4.9 & 5.7 \\
\hline 14 & 1.5 & 30 & 0.8838 & 0.90 & 0.89 & 4.74 & 5.1 & 5.2 \\
\hline 15 & 1.5 & 40 & 0.891 & 0.91 & 0.90 & 4.62 & 5 & 5 \\
\hline
\end{tabular}

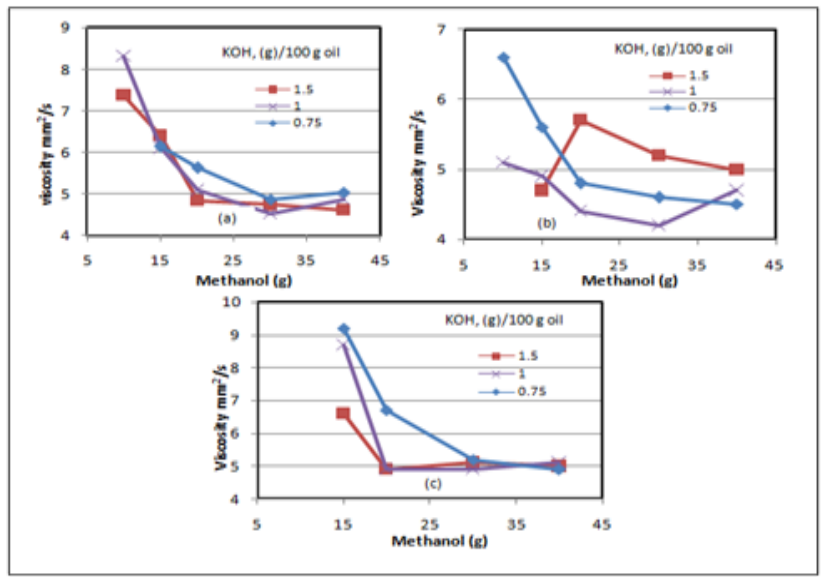

Fig .2. Viscosity of FAME at $40^{\circ} \mathrm{C}$, (a) WPO, (b) WHO and (c) WTO 


\section{- Cloud Point and Pour Point}

Figure (3) reveals that the cloud point for (WHO) ranged between $\left(-2-2.5^{\circ} \mathrm{C}\right)$, for (WTO) between ($\left.1.75-5^{\circ} \mathrm{C}\right)$ and for (WPO) between $\left(15-25^{\circ} \mathrm{C}\right)$. The Pour point results presented in Figure (4) revealed that it ranged between $\left(-8--3^{\circ} \mathrm{C}\right)$ for (WHO), between $\left(-5.5--0.5^{\circ} \mathrm{C}\right)$ for (WTO) and between (4$14^{\circ} \mathrm{C}$ ) for (WPO). It may be concluded that (WPO) is solid at room temperature because its main constituent is Palmitic acid. The FAME produced from (WPO) would not be suitable for cold weather as it will block vehicles' hoses and pipes. The cloud point and pour point limits of Egyptian petro-diesel are $9^{\circ} \mathrm{C}$ and $6^{\circ} \mathrm{C}$, respectively. Thus most esters produced from WHO and WTO would conform to the Egyptian specifications, however all esters produced from WPO would not be suitable for local use in cold conditions.

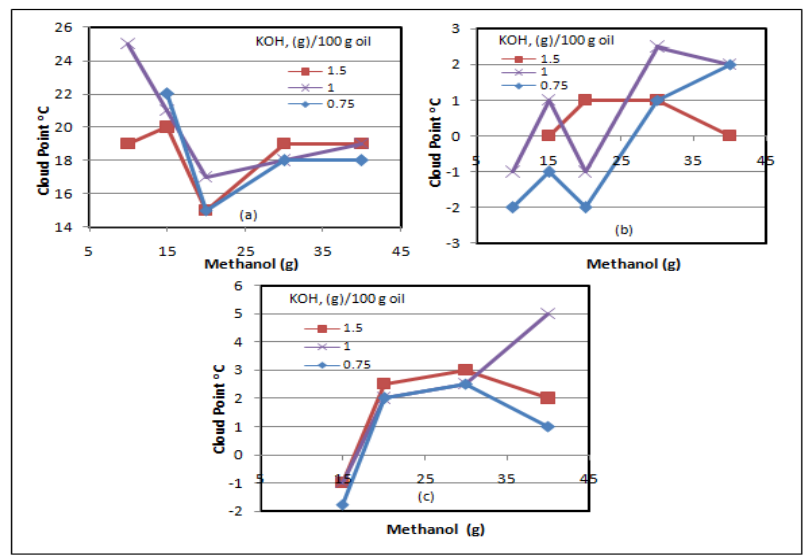

Fig .3. Cloud Point of FAME, (a) WPO, (b) WHO and (c) WTO

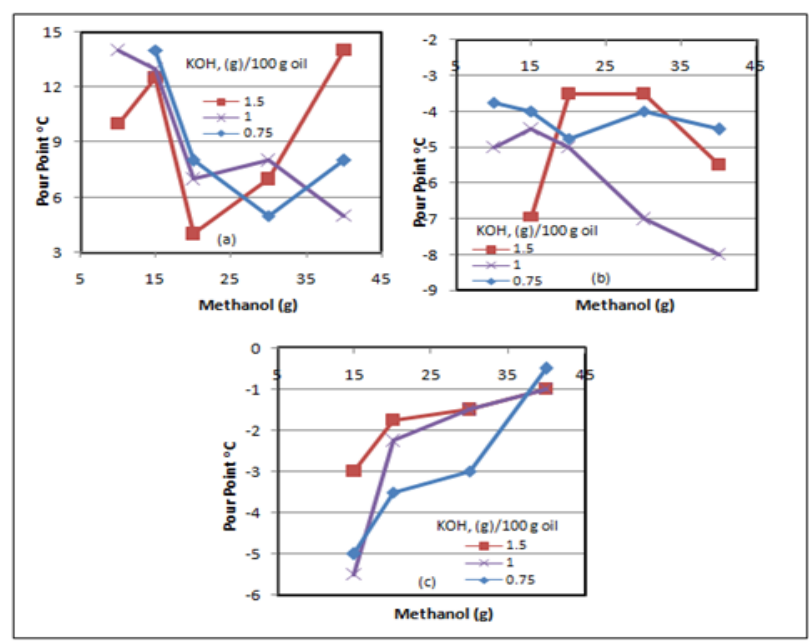

Fig .4. Pour Point of FAME, (a) WPO, (b) WHO and (c) WTO

\section{SAPONIFICATION VALUE:}

The saponification value is defined as the milligrams of $\mathrm{KOH}$ required to saponify one gram of oil. The obtained saponification value for biodiesel produced from all the tested waste frying oils (WFO) was higher than that of the WFO feed. This is not the case when virgin vegetable oil is used for biodiesel production. This is attributable to the chemical degradation during frying when reactions such as cyclization and polymerization take place. The saponification value of WPO was $160.78 \mathrm{mg} \mathrm{KOH} / \mathrm{g}$ oil, while that of its esters ranged between 162.69 and $201.96 \mathrm{mg} \mathrm{KOH} / \mathrm{g}$ oil. The saponification value of WHO was $150.66 \mathrm{mg}$ $\mathrm{KOH} / \mathrm{g}$ oil, while that of its esters ranged between 140.25 and $252.45 \mathrm{mg} \mathrm{KOH} / \mathrm{g}$ oil. The saponification value of WTO was $135.25 \mathrm{mg} \mathrm{KOH} / \mathrm{g}$ oil, while that for its esters ranged between 145.86 and $238.43 \mathrm{mg} \mathrm{KOH} / \mathrm{g}$ oil. The obtained saponification values for the different oils are presented in Figure (5).

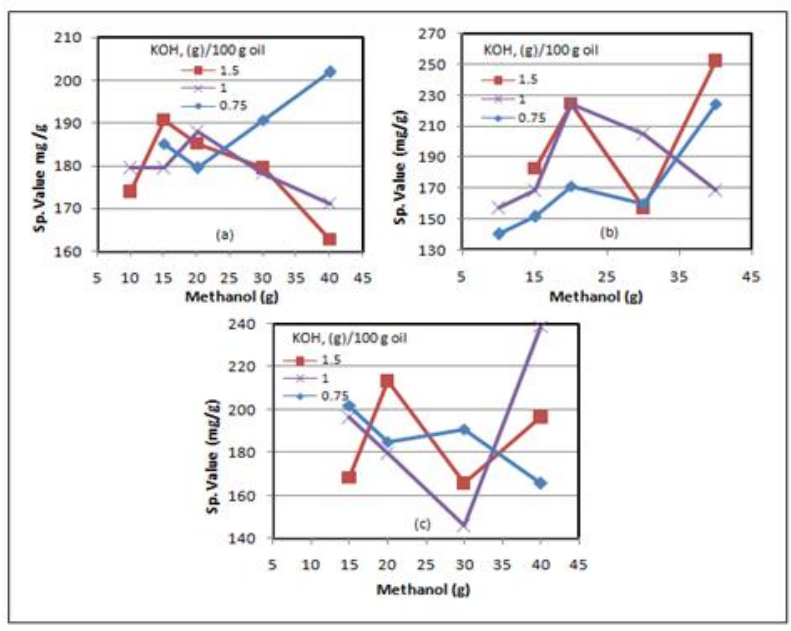

Fig .5. Saponification Value of FAME, (a) WPO, (b) WHO and (c) WTO

\section{GAS CHROMATOGRAPHY (GC) ANALYSIS:}

Table (3) presents the results of the GC analysis of the produced FAME from WPO. The fatty acid content is the major factor affecting the properties of biodiesel. The biodiesel derived from the sample of waste cooking oil subjected to GC contained palmitic acid, stearic acid, oleic acid, and linoleic acid. The saturated fatty acid content of the waste cooking oil was approximately $60 \%$ corresponding to a Cold Filter Plugging Point (CFPP) of $\left(6-14^{\circ} \mathrm{C}\right)$. 

http://dx.doi.org/10.21622/RESD.2017.03.2.189

Table 3. GC Results of FAME Produced from WPO

\begin{tabular}{|c|c|c|c|c|c|c|c|}
\hline $\mathrm{KOH}(\mathrm{g})$ & $\mathrm{CH}_{3} \mathrm{OH}(\mathrm{g})$ & $\begin{array}{c}\mathrm{A} \\
\text { Palmitate }\end{array}$ & $\begin{array}{c}\mathrm{B} \\
\text { Linoleate }\end{array}$ & $\begin{array}{c}\mathrm{C} \\
\text { Oleate }\end{array}$ & $\begin{array}{c}\mathrm{D} \\
\text { Stearate }\end{array}$ & Saturated & Unsaturated \\
\hline 0.75 & 20 & 49 & 5.939 & 38.8 & 6.202 & 55.241 & 44.758 \\
\hline 0.75 & 30 & 52.7 & 4.687 & 36.6 & 6.008 & 58.677 & 41.323 \\
\hline 0.75 & 40 & 53.2 & 5.123 & 35.8 & 5.878 & 59.042 & 40.958 \\
\hline 1 & 20 & 50 & 5.913 & 38.3 & 5.787 & 55.745 & 44.256 \\
\hline 1 & 30 & 51.8 & 5.427 & 37.1 & 5.744 & 57.5 & 42.501 \\
\hline 1 & 40 & 52.9 & 5.333 & 35.8 & 5.928 & 58.84 & 41.161 \\
\hline 1.25 & 20 & 47.7 & 6.058 & 40.2 & 6.073 & 53.737 & 46.264 \\
\hline 1.25 & 30 & 64.8 & 4.152 & 26.6 & 4.432 & 69.226 & 30.775 \\
\hline 1.25 & 40 & 53 & 5.232 & 35.8 & 6.024 & 58.982 & 41.018 \\
\hline 1.5 & 20 & 57.1 & 4.854 & 32.1 & 5.857 & 62.996 & 37.003 \\
\hline 1.5 & 30 & 53.4 & 5.31 & 35.4 & 5.915 & 59.294 & 40.706 \\
\hline
\end{tabular}

\section{CONCLUSION}

Laboratory trans-esterification experiments have been carried out to determine the effect of the amount of catalyst and methanol on the FAME yield produced from different waste frying oils at a reaction temperature of $60-70^{\circ} \mathrm{C}$ ), a reaction time of $120 \mathrm{~min}$ and at an agitation speed of $400 \mathrm{rpm}$. Since the feedstock has been collected from different sources, there was a significant difference in the chemical and physical properties of the produced biodiesel.

The yield, conversion, density, viscosity, cloud point, pour point and saponification value of the produced FAME have been experimentally determined for different $\mathrm{KOH}$ and methanol to oil ratios. The optimum amount of catalyst and methanol for the three types of waste oils investigated are respectively $(1 \mathrm{~g} \mathrm{KOH}-40 \mathrm{~g}$ methanol) for (WPO), $(1.5 \mathrm{~g} \mathrm{KOH}-40 \mathrm{~g}$ methanol) for (WTO), and $(1 \mathrm{~g} \mathrm{KOH}$ - $20 \mathrm{~g}$ methanol)for (WHO). The highest yield was obtained from (WHO) due to its relatively low FFA content.

The densities and viscosities of the biodiesel produced from the three waste cooking oils lie within the ASTM standard except for the runs using low amounts of methanol. The cold flow properties of the (WTO) and (WHO) conform to the Egyptian specifications; however, all the esters produced from WPO were not suitable for use in cold conditions. The best biodiesel properties were obtained from (WHO), followed by that obtained from (WTO) and then (WPO) owing to its high palmitic acid content.

\section{REFERENCES}

[1] L.C. Meher, D.V. Sagar and S.N. Naik. "Technical aspects of biodiesel production by transesterification: A review." Renewable and Sustainable Energy Reviews, vol.10, pp. 248268, 2006.

[2] K.M. Shereena and T.Thangaraj. "Biodiesel: An alternative fuel produced from vegetable oils by transesterification." Electronic Journal of Biology, vol.5 3, pp. 67-74, 2009.

[3] M. S. Kumar, A. Kerihuel, J. Bellttre and M. Tazerout. "Ethanol animal fat emulsions as a diesel engine fuel; Part 2: Engine test analysis." Fuel, vol. 85, pp. 2646-2652, 2006.

[4] "Pacific Biodiesel - Recycle Used Cooking Oil \& Grease Trap Waste." Available: www.biodiesel.com/biodiesel/history. :[ March 3, 2016].

[5] C.Y.May, Y. C. Liang, C. S. Foon, M. A. Ngan, C. C. Hook and Y. Basiron. "Key fuel properties of palm oil alkyl esters." Fuel, vol. 84, pp. 1717-20, 2005.

[6] K. Anand, A. Ranjan and P. S. Mehta. "Estimating the viscosity of vegetable oil and biodiesel fuels." Energy Fuels vol. 24, pp. 664672, 2010. 
[7] M. S. Kumar, A. Ramesh and B. Nagalingam. "An experimental comparison of methods to use methanol and jatropha oil in a compression ignition engine." Biomass and Bioenergy, vol. 25, pp. 309-18, 2003.

[8] N. Ozsezen, M.Canakci, A.Turkcan and C.Sayin. "Performance and combustion characteristics of a DI diesel engine fueled with waste palm oil and canola oil methyl esters." Fuel, vol. 88, pp. 629636, 2009.

[9] R. K. Pandey, A. Rehman, R.M. Sarviya and S. Dixit. "Automobile emission reduction and environmental protection through use of green renewable fuel." HYDRO NEPAL, vol. 7, pp. 6570, 2010.

[10] S. Behzadi and M. M. Farid. "Production of biodiesel using a continuous gas-liquid reactor." Bioresource Technology, vol. 100, pp. 683-689, 2009.

[11] M. Canakci and A. N. Ozsezen. "Evaluating waste cooking oils as alternative diesel fuel." GU Journal of Science, vol. 18, pp. 81-91, 2005.

[12] B. Chhetri, K. C. Watts and M. R. Islam. "Waste cooking oil as an alternate feedstock for biodiesel production." Energies, vol. 1 pp. 3-18, 2008.
[13] Z. Utlu and M. S. Kocak. "The effect of biodiesel fuel obtained from waste cooking oil on direct injection diesel engine performance and exhaust emissions." Renewable Energy, vol. 33, pp. 1936-41, 2008.

[14] M. A. Hess, M. J. Haas, T. A. Foglia and W. N. "Marmereffect of antioxidant addition on NOx emissions from biodiesel." Energy Fuel, vol. 19(4), pp. 1749-54, 2005.

[15] J. P. Szybist, S. R. Kirby and A. L. Boehman. "NOx emissions of alternative diesel fuels: a comparative analysis of biodiesel and FT diesel." Energy Fuel, vol. 19(4), pp. 1484-92, 2005.

[16] C. A. Sharp, S. A. Howell and J. Jobe. "The effect of biodiesel fuels on transient emissions from modern diesel engines - part I: regulated emissions and performance." SAE paper. 2000; vol. 1, pp. 1967-85.

[17] S. A. El Sherbiny, A. A. Refaat and S. T. El Sheltawy. "Production of biodiesel using the microwave technique." Journal of Advanced Research, vol.1, pp. 309-314, 2010. 